\title{
Mitochondrial myopathy: a genetic study of 71 cases
}

\author{
A E HARDING, R K H PETTY, AND J A MORGAN-HUGHES \\ From the Department of Clinical Neurology, Institute of Neurology and National Hospital for Nervous \\ Diseases, Queen Square, London WC1N 3BG.
}

SUMMARY Of 71 index cases with histologically defined mitochondrial myopathy, $13(18 \%)$ had relatives who were definitely affected with a similar disorder. Eight familial cases from four families were confined to a single generation. In five families maternal transmission to offspring occurred. There were no instances of paternal transmission, but one patient had an affected cousin in the paternal line. No consistent clinical syndrome or pattern of inheritance emerged for any identified defect of the mitochondrial respiratory chain, localised biochemically in 41 cases. Overall, the recurrence rate was $3 \%$ for sibs and $5.5 \%$ for offspring of index cases.

Review of published reports of familial cases of mitochondrial myopathy suggests that the ratio of maternal to paternal transmission is about $9: 1$. We conclude that these disorders may be caused by mutations of either nuclear or mitochondrial genes.

The term mitochondrial myopathy (MM) is applied to a clinically and biochemically heterogeneous group of disorders which share the common feature of major mitochondrial structural abnormalities in skeletal muscle. Ragged red fibres, seen with the modified Gomori trichrome stain, ${ }^{1}$ are the major morphological hallmark of these diseases. They were described initially in patients presenting with syndromes of chronic progressive external ophthalmoplegia (CPEO) or proximal myopathy or both, often with weakness induced or enhanced by exertion. More recently they have been reported in children and adults with complex multisystem disorders predominantly or exclusively affecting the central nervous system, giving rise to clinical features such as psychomotor retardation, dementia, pigmentary retinopathy, ataxia, seizures, movement disorders, stroke-like episodes, deafness, and peripheral neuropathy in various combinations. Involvement of other systems, such as the heart, endocrine glands, and haemopoietic tissues, has also been reported. ${ }^{2} 3$ In vitro studies of mitochondrial metabolism in patients with MM have identified a variety of defects of the respiratory chain and oxidative phosphorylation system, none of which is associated with a specific or consistent clinical syndrome. ${ }^{2-4}$

The majority of reported cases of MM have no affected relatives but families containing more than one affected subject have been described. It has

Received for publication 11 August 1987.

Revised version accepted for publication 23 September 1987. been suggested that MM is caused by mutations of $\vec{\varphi}$ mitochondrial DNA, as maternal transmission to offspring appears to be more common than paterng transmission, and mitochondrial DNA is exclusive $\$$ maternally inherited. ${ }^{56}$ This paper presents pede gree data on 71 patients with histologically defined $\mathrm{MM}$ and analyses 105 familial cases from published reports.

\section{Patients and methods}

The index cases were ascertained from the muscle biopsy files at the National Hospital for Nervous Diseases, London, over the period 1969 to 1986. Mitochondrial myopathy was defined by the presence of $4 \%$ or more of muscle fibres showing enhanced peripheral and intermyofibrillar activity of succinate dehydrogenase. ${ }^{3} \mathrm{~A}$ total of 71 patients from 69 families was identified, 52 of whom were reviewed by the authors between 1983 and 1986. A $\rightarrow$ detailed family history was taken from them and wherever possible their first degree relatives were $N$ examined. Details of the remaining 19 patients were obtained from hospital records; four had died and 15 were unavailable for study.

\section{Results}

Clinical AND BIOCHEMICAL FEATURES

The clinical features of 66 of the 71 patients have been described elsewhere. ${ }^{3}$ There were 38 females and 33 males. The age of onset of symptoms ranged from birth to 68 years, but was before the age of 20 
TABLE 1 Mitochondrial myopathy: clinical syndrome and incidence of affected relatives.

\begin{tabular}{lll}
\hline Clinical syndrome & $\begin{array}{l}\text { No of index } \\
\text { cases }\end{array}$ & $\begin{array}{l}\text { No of index cases with } \\
\text { affected relatives }\end{array}$ \\
\hline $\begin{array}{l}\text { CPEO and limb weakness } \\
\begin{array}{l}\text { Fatigable proximal limb } \\
\text { weakness }\end{array}\end{array}$ & 36 & 4 \\
$\begin{array}{l}\text { Predominantly or exclusively } \\
\text { CNS disease (ataxia, } \\
\text { dementia, seizures, } \\
\text { involuntary movements etc) }\end{array}$ & 12 & 6 \\
Total & 23 & 3 \\
\hline
\end{tabular}

years in two-thirds of cases. The clinical presentation was very variable. Three broad clinical subgroups of cases could be identified: (1) a combination of CPEO with or without proximal weakness $(55 \%)$; (2) fatigable limb weakness alone $(18 \%)$; and (3) those with clinical features, such as ataxia, dementia, deafness, involuntary movements, and seizures, predominantly or exclusively arising from the CNS $(27 \%)$.

In vitro studies of mitochondrial metabolism, ${ }^{7}$ performed in 41 patients, localised defects to complex I (NADH-ubiquinone oxidoreductase) in 26 cases and to complex III (ubiquinol-cytochrome c reductase) in a further nine. One had defects involving complex III and complex IV, and another a defect of complex V (mitochondrial ATPase). In two patients oxygen uptake rates were reduced with all substrates tested; in two others in vitro studies of mitochondrial metabolism were normal.

FAMILY STUDIES

The 71 index cases were members of 69 families. A

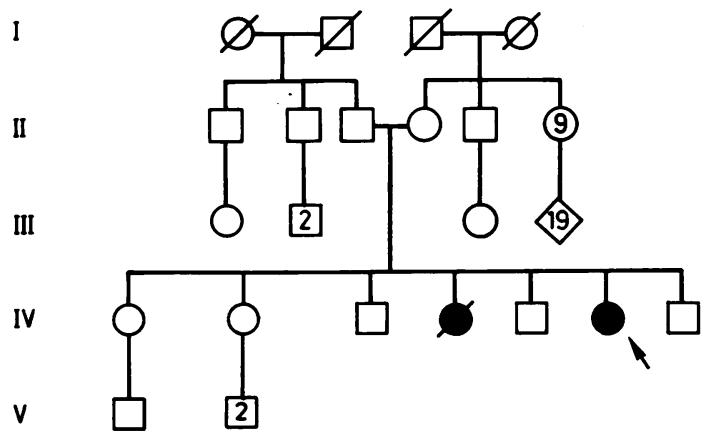

FIG 1 Pedigree of a family containing two sisters with fatigable muscle weakness and intermittent metabolic acidosis; the older sister died at the age of 22 after developing cardiac failure secondary to lactic acidaemia. The younger girl was found to have ragged red fibres on muscle biopsy, and a defect at complex I of the respiratory chain. The patients' parents were clinically normal. total of 13 index cases $(18 \cdot 3 \%)$ had relatives who were definitely and similarly affected; all of these had symptoms. Half of the index cases with myopathy alone had affected relatives, but the majority of the patients with CNS disease did not (table 1). Five patients, all with complex I deficiency, had similarly affected relatives in whom the diagnosis was confirmed on clinical examination, light microscopy of skeletal muscle biopsies, and, in two cases, in vitro studies of mitochondrial metabolism. In four of these five families the clinical syndrome was of a fatigable myopathy. There were two affected sib pairs with clinically normal parents, one of which is shown in fig 1 ; the other pair were both index cases. ${ }^{8} \mathrm{~A}$ further family contained an affected mother and daughter who were both index cases (cases 5 and 6 of Petty et $a l^{3}$ ). In another kindred, the mother and monozygous twin of the index case (case 3 of Petty $e t \mathrm{al}^{3}$ ) gave a history of fatigability and were found to have mild proximal muscle weakness and pigmentary retinopathy (fig 2 ). In the fifth kindred, a female with dementia, retinopathy, ataxia, stroke-like episodes, and myopathy (case 21 of Petty $e t a l^{3}$ ) had a son with mild mental retardation, infrequent seizures, and retinopathy. His muscle biopsy showed occasional ragged red fibres but in vitro studies of mitochondrial metabolism were normal.

In three further families, the index cases gave a history of affected relatives which was confirmed clinically but not histologically. One of these, a female with a retinitis pigmentosa-like retinopathy, dementia, ataxia, and myopathy (case 15 of Petty et $a l^{3}$ ), has two children and a maternal grandchild with retinitis pigmentosa alone. The index case has no identifiable defect of mitochondrial metabolism. A female with CPEO and proximal myopathy and complex III deficiency had a daughter with ptosis and fatigue who died suddenly for no obvious reason at the age of 15. Another female with CPEO and proximal muscle weakness, with no identifiable defect of mitochondrial metabolism, has an affected

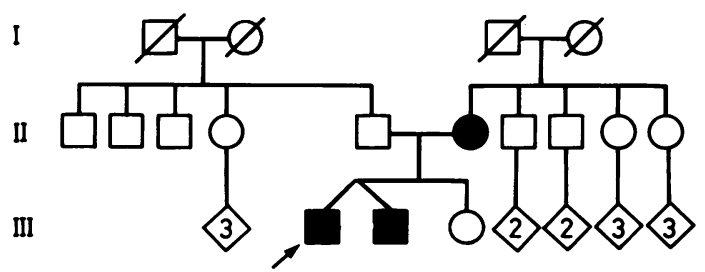

FIG 2 Pedigree of a family containing monozygotic twins with complex I deficiency giving rise to fatigable myopathy and 'salt and pepper' retinopathy. Their mother was mildly but similarly affected. 


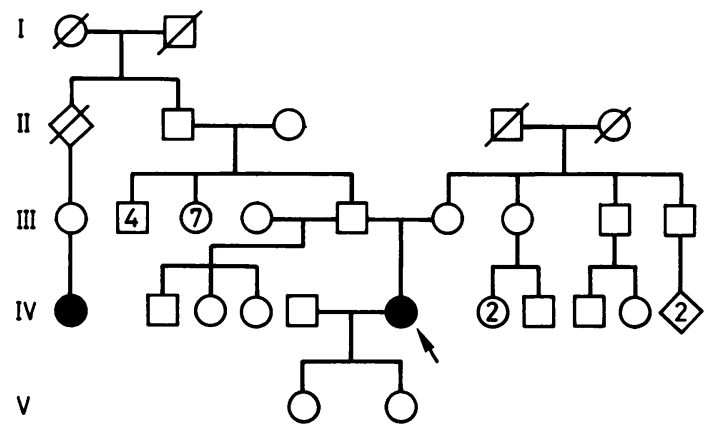

FIG 3 The two affected females in this family had CPEO and proximal weakness in the limbs. Note that several intervening male relatives were normal.

cousin with several normal intervening male relatives (fig 3).

Six further patients gave a history of affected relatives but these were unavailable for examination. The presence of ptosis was confirmed by examining hospital records and photographs of one patient's sister's daughter. The index case had CPEO and proximal weakness and complex III deficiency (case 1 of Petty et $a l^{3}$ ). A male with complex I deficiency and ataxia. personality change, and proximal muscle weakness developing in the third decade of life had an older brother who died at the age of 25 . He was always small and of low intelligence. When he was 19 he had the first of several stroke-like episodes, associated with focal seizures, which led to progressive disability and dementia. The dead brother of an Iranian male with CPEO and proximal weakness was similarly affected; their parents were first cousins. In the four other cases the family history was vague and could not be confirmed; these relatives were not therefore considered as secondary cases. Two (one male, one female) had children with 'droopy eyelids', another

TABLE 2 Mitochondrial myopathy: summary of pedigree data.

\begin{tabular}{lll}
\hline & $\begin{array}{l}\text { No of } \\
\text { families }\end{array}$ & Site of defect \\
\hline $\begin{array}{l}\text { Affected sib pairs } \\
\text { (parental consanguinity in one } \\
\text { Iranian family) }\end{array}$ & 4 & I in three \\
$\begin{array}{l}\text { Parent-offspring } \\
\text { Maternal transmission }\end{array}$ & 5 & $\begin{array}{l}\text { I in three, III in one, } \\
\text { none identified in one }\end{array}$ \\
$\begin{array}{l}\text { Paternal transmission } \\
\text { Index case and sister's daughter } \\
\text { Index case and paternal cousin }\end{array}$ & 1 & $\begin{array}{l}\text { III } \\
\text { None identified }\end{array}$ \\
\hline
\end{tabular}

a paternal cousin with the same symptom, and the $\frac{\mathbb{D}}{?}$ mother of a patient with CNS disease (case 9 of $\stackrel{\mathbb{P}}{-}$ Petty $e a^{3}$ ) was said to have been ataxic in later life. $\overrightarrow{\vec{A}}$

Thus a total of 12 secondary cases was ascertained, in addition to the 71 index cases. A further? 88 relatives of index cases (18 mothers, eight $\frac{\bar{c}}{\bar{c}}$

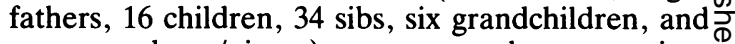
seven nephews/nieces) were normal on examina- $\varrho$ tion. The parents of four patients (one of whom had an affected sib by history) were consanguineous, but $\vec{\circ}$ all these came from populations where consanguine- ous marriages are common. The pedigree data are $\vec{\omega}$ summarised in table 2 . There was no correlation? between the biochemical defect and any possible mode of inheritance.

The recurrence rates in various relatives of index cases are summarised in table 3 , using information in $^{\circ}$ from the 66 families in which adequate pedigree $N_{\infty}^{N}$ data were available. A total of $2.9 \%$ of sibs of eithero sex of index cases was definitely and similarly affected and $5.5 \%$ of children (aged 20 or over) of $\square$ index cases were affected; the incidence was highestco among children of female patients with a recurrence क rate of about $8 \%$. There was no definite evidence of $\vec{\varphi}$ paternal transmission to offspring.

\section{OTHER GENETIC DATA}

Reproductive fitness was compared between malê̄ं. and females aged 35 or over. The mean number of children fathered by 23 males was $1 \cdot 48 \pm 1 \cdot 24, \stackrel{2}{\varrho}$ compared to a mean of $2 \cdot 20 \pm 1.82$ for 20 females. $\unrhd$ This difference is not significant $(t=1 \cdot 53, \mathrm{p}>0 \cdot 1)$. $\overrightarrow{\overrightarrow{0}}$ Five of the females and seven of the males had not 3 reproduced. There was no demonstrable birth order

TABLE 3 Mitochondrial myopathy: recurrence rates in $\overline{3}$ relatives of index cases.

\begin{tabular}{|c|c|c|c|}
\hline Occurrence of disease in & Sex & $\begin{array}{l}\text { Proportion } \\
\text { affected }\end{array}$ & $\%$ \\
\hline Sibs of index cases & Either & $6 / 208$ & $2 \cdot$ \\
\hline Sibs of female index cases & $\begin{array}{l}\text { Male } \\
\text { Female }\end{array}$ & $\begin{array}{l}0 / 56 \\
3 / 57\end{array}$ & $\begin{array}{l}0 \\
5 \cdot 3\end{array}$ \\
\hline Sibs of male index cases & $\begin{array}{l}\text { Male } \\
\text { Female }\end{array}$ & $\begin{array}{l}3 / 51 \\
0 / 44\end{array}$ & $\begin{array}{l}5 \cdot 9 \\
0\end{array}$ \\
\hline Offspring (aged $>20$ ) of index cases & Either & $3 / 54$ & $5 \cdot 5$ \\
\hline Offspring of male index cases & Either & $0 / 17$ & 0 \\
\hline Offspring of female index cases & $\begin{array}{l}\text { Male } \\
\text { Female }\end{array}$ & $\begin{array}{l}1 / 16 \\
2 / 21\end{array}$ & $\begin{array}{l}6 \cdot 2 \\
9 \cdot 5\end{array}$ \\
\hline Mothers of female index cases & & $1 / 38$ & $2 \cdot 6$ \\
\hline Mothers of male index cases & & $1 / 33$ & $3 \cdot$ \\
\hline Fathers of index cases & & $0 / 71$ & 0 \\
\hline Uncles/aunts of index cases & & $0 / 328$ & 0 \\
\hline Nephews of index cases & & $0 / 93$ & 0 \\
\hline $\begin{array}{l}\text { Nieces of index cases } \\
\text { Sisters' daughters }\end{array}$ & & $1 / 42$ & $2 \cdot$ \\
\hline Brothers' daughters & & $0 / 43$ & 0 \\
\hline First cousins of index cases & & $0 / 348$ & 0 \\
\hline Second cousins of index cases & & 1 & \\
\hline
\end{tabular}


effect in the series overall or in the 53 singleton cases where sufficient pedigree data were available, using the method of Haldane and Smith. ${ }^{9}$ Parental ages at the time of birth were known for 36 singleton cases born between 1915 and 1965. Mean paternal age was $31.6 \pm 6.8$ years, and mean maternal age was $27.6 \pm 4.6$ years. In England and Wales in 1961 mean paternal age was $30.2 \pm 6.7$ years, and mean maternal age was $27 \cdot 1 \pm 5 \cdot 8$ years. ${ }^{10}$

REVIEW OF PUBLISHED REPORTS

Previous reports of patients with morphologically defined MM who had similarly affected relatives were reviewed. Only those with adequate clinical, histological, or pedigree data were included. In 18 families, 46 out of 82 sibs were affected but their parents were normal. ${ }^{11-26}$ Parental consanguinity was present in one of the 18 kindreds. There were 19 affected males and 27 females. The clinical syndrome was variable in these patients but usually consistent within families. An infantile onset myopathy with lactic acidosis, associated with cytochrome oxidase deficiency, was seen in four sibships. The three clinical subgroups of MM delineated by Petty et $\mathrm{al}^{3}$ were approximately equally represented in the other 14 ; none of these had been studied biochemically.

In 22 families there were affected subjects in more than one generation and transmission was exclusively maternal. ${ }^{5} 61227-40$ These families contained 40 affected females who had 48 affected and 54 normal children. Again, there was a wide spectrum of clinical features with much more variation between than within families. The syndrome of myoclonic epilepsy with mitochondrial myopathy occurred in four kindreds, including a particularly large one reported by Rosing et al. ${ }^{31}$ Patients from two other families had the syndrome of mitochondrial encephalomyopathy with stroke like episodes (MELAS), and the majority of the rest had CPEO or proximal myopathy or both. In vitro studies of mitochondrial metabolism were not described in any of these kindreds.

Paternal transmission of MM to offspring appears to be relatively rare, as discussed by Egger and Wilson. ${ }^{6}$ The family reported by Lapresle et $a l^{42}$ was most unusual clinically as the affected members had a distal myopathy. Jankowicz et al ${ }^{43}$ reported a father and son with pigmentary retinopathy, CPEO, myopathy, and ataxia, associated with a cardiac conduction defect in the son who had mitochondrial abnormalities on muscle biopsy. A similar, but variable, spectrum of clinical features was observed in seven patients in another pedigree which appears to exhibit autosomal dominant inheritance. ${ }^{44}$ One male with CPEO and limb weakness had a daughter with CPEO, retinopathy, cardiac arrhythmias, and proximal myopathy. The father had ragged red fibres on muscle biopsy but his daughter did not. In the kindred of Kinoshita and Wakata. ${ }^{+5}$ a father and son had proximal myopathy associated with lipid storage and ragged red fibres.

Vilming et $a l^{+h}$ described two sisters with adult onset dementia, ptosis, and proximal muscle weakness; muscle biopsy showed ragged red fibres. The father of these sisters had a similar clinical syndrome of dementia, myopathy, and ptosis. A father and son with cytochrome $b$ deficiency were reported by Spiro et $a l^{47}$; other biochemical results from the son's muscle are compatible with a lesion at complex III of the repiratory chain. The father developed ataxia and proximal neurogenic weakness in the fourth decade of life, whereas the son had retarded intellectual development, retinopathy, CPEO, ataxia, myoclonus, and proximal muscle weakness.

Affected cousins with cytochrome c oxidase deficiency and apparently normal parents have been described. ${ }^{48}$ In a number of other pedigrees it is difficult to be sure whether some subjects were affected or not and the pattern of transmission is unclear. ${ }^{6} 114149-55$ For example, the mothers and grandmother of two cousins with mitochondrial encephalomyopathy were deaf. ${ }^{52}$ The mother of two sibs with myoclonus and $\mathrm{MM}$ had an abnormal EEG, and the mother of another similar case had frequent falls for about 10 years before her death aged $33 .{ }^{54}$ In a further kindred, ${ }^{49}$ the brother, father, and one cousin of a patient with CPEO and proximal myopathy had ptosis but no other neurological abnormalities; muscle biopsies were not performed on the relatives. In two families described by Bastiaensen et al, ${ }^{11}$ which appear to show numerous examples of paternal transmission, all the patients, apart from the index cases, had only "slight ptosis". Muscle biopsy from one relative showed "minimal mitochondrial abnormalities". The father of two patients with proximal myopathy had mildly raised serum lactate concentrations. ${ }^{53}$ It is particularly difficult to assess the significance of abnormal investigations alone.

This problem is relevant to some of the families described by Egger and Wilson. ${ }^{6}$ In their family Gr, two clinically normal offspring of females were considered to be affected on the basis of raised creatine kinase levels, but similar findings in two daughters of male patients "were not viewed as indicative of mitochondrial cytopathy". In family $\mathrm{Gal}$, three maternal relatives of the index case were considered to be affected because they had chronic nephropathy. Two patients in family $\mathrm{H}$ were diagnosed as having MM because increased jitter was found on single fibre electromyography. The mother 
TABLE 4 Mitochondrial myopathy: summary of pedigree data from published reports and present study.

\begin{tabular}{|c|c|c|}
\hline & This study & Previous reports \\
\hline $\begin{array}{l}\text { Familial cases confined to a } \\
\text { single generation } \\
\text { No of families } \\
\text { No affected } \\
\text { No unaffected } \\
\text { Sex ratio of patients M:F } \\
\text { Parental consanguinity }\end{array}$ & $\begin{array}{c}4 \\
8 \\
20 \\
4: 4 \\
1\end{array}$ & $\begin{array}{l}18 \\
46 \\
82 \\
19: 27 \\
1\end{array}$ \\
\hline $\begin{array}{l}\text { Cases in more than one } \\
\text { generation } \\
\text { No of families } \\
\text { No of patients with affected } \\
\text { mothers } \\
\text { No of patients with affected } \\
\text { fathers }\end{array}$ & $\begin{array}{l}5 \\
7 \\
0\end{array}$ & $\begin{array}{l}28 \\
52 \\
8\end{array}$ \\
\hline
\end{tabular}

of one definitely affected subject in this family had clinical features suggestive of MM (myopathy and deafness); muscle biopsies from this female and another mother with nephropathy alone did not show ragged red fibres. ${ }^{29}$

The pedigree data obtained from published reports are summarised in table 4, together with the results of the present study. Familial cases of MM were confined to a single sibship in a total of 22 families and parental consanguinity was present in two of these. Forty-two mothers had affected children, compared to only seven fathers. Looking at the data in another way, which gives the total number of transmissions as opposed to parents, maternal transmission occurred 59 times compared to eight times for paternal transmission. Maternal transmission occurred exclusively in 27 out of the 33 families containing patients in two or more generations.

Table 5 shows the ratio of affected:unaffected children of patients who had affected children in pedigrees exhibiting vertical transmission. It was impossible to exclude index cases as they could rarely be identified. Patients who had only unaffected children are shown separately, as ascertain-

TABLE 5 Mitochondrial myopathy: ratios of affected: unaffected children of patients in families with affected members in more than one generation.

\begin{tabular}{lll}
\hline Parent & Children & \\
\cline { 2 - 3 } & Affected $(M: F)$ & Unaffected $(M: F)$ \\
\hline Female $(n=42)$ & $58(22: 36)$ & $57(26: 31)$ \\
Male $(n=7)$ & $8(6: 2)$ & $18(7: 11)$ \\
\hline
\end{tabular}

These figures only include patients who had affected children; in addition there were six males and three female patients in these families who had a total of 20 normal children (eight males and 12 females). ment of these from published reports is unlikely to be complete. In the offspring of affected females, $\rightarrow$ the ratio was close to $50: 50$. Although the propor $\overrightarrow{\vec{c}}$ tion of affected girls appears to be high, the ratio of affected:unaffected girls was also approximately등 $50: 50$. The proportion of affected offspring of affected males was less than $50 \%$, but the numbers are too small to assess statistically.

\section{Discussion}

The clinical and biochemical heterogeneity of the mitochondrial myopathies makes it difficult to draws any definite conclusions about their genetic basis Some pedigrees suggest autosomal recessive ori dominant inheritance. There is no evidence in favour of a significant contribution to the aetiologyer of MM from mutant genes on the X chromosome male to male transmission occurs and there was noo obvious difference in disease severity between males and females in this study. Data from both our series and the familial published cases reviewed indicateo that maternal transmission to offspring is far mores frequent than paternal transmission. Hudgson et a $l_{\vec{c}}$ first suggested that this could be explained on theop basis of mitochondrial inheritance, and this hy thesis was later supported by Egger and Wilso

Mitochondrial DNA is exclusively maternatis inherited in many species, including humans. ${ }^{56+5 \delta}$ This closed circular molecule, $16.5 \mathrm{~kb}$ in length, has been sequenced in man and other mammals. ${ }^{58}$ I 8 encodes for 13 of the 67 or so components of th $\overrightarrow{5}$ respiratory chain and the oxidative phosphorylatio $\$$ system in the mitochondrial inner membrane; seve subunits of complex I, cytochrome b (complex III) subunits I, II, and III of cytochrome oxidase (complex IV), and subunits 6 and 8 of mitochondria承 ATPase (complex V) ${ }^{5960}$ Given that the majority of our patients have biochemical defects localised $t \theta$. complex I or complex III of the respiratory chain, if is reasonable to suggest that these may resule from mutations of mitochondrial DNA.

Nevertheless, if MM is mitochondrially inherite in pedigrees indicating maternal transmission theoretically all the offspring of affected females should be affected and only about half of them are? There are two possible explanations for this. One if that some subjects carrying the abnormal mitow chondrial genotype do not express it clinically oo histologically. The diagnosis of MM is sometimę difficult to confirm or exclude with certainty, an $\$$ this is one factor which makes pedigree analysis sêp difficult in these diseases. We have used the presence of ragged red fibres in skeletal muscle as the major diagnostic criterion in this series, as this is the most consistent laboratory finding. These may $b \overrightarrow{8}$ 
scanty or absent in clinically affected subjects in some families, ${ }^{3} 31$ which is not surprising given that muscle is clinically unaffected in a significant proportion of patients. Even in vitro studies of muscle mitochondrial metabolism are not always diagnostic in this context, as was shown in the son of case 21 in this series. ${ }^{3}$

An alternative explanation for reduced penetrance of an abnormal mitochondrial genotype in any single maternal line is that ova, collectively or individually, contain a heterogeneous population of mitochondrial DNA molecules. This hypothesis is also compatible with the variable expression in different tissues, and the partial deficiencies seen in patients with defects of the respiratory chain. Although mitochondrial DNA heteroplasmy is not known to occur in man, it has been shown in Drosophila $^{61}$ and a single maternal line of Holstein cows. ${ }^{62}$ Given the high mutation rate of mitochondrial DNA, ${ }^{64}$ which leads to extensive nucleotide sequence divergence between different maternal lines, ${ }^{65-69}$ it would be rather surprising if mitochondrial DNA heteroplasmy did not occur.

There are explanations other than mitochondrial inheritance for the excess of maternal transmission seen in MM, for example, infertility in male patients with a dominantly inherited disorder. Theoretically, relative infertility in males with $\mathrm{MM}$ may be expected, as fertilisation requires much greater energy production from spermatozoa than ova. In this study, males had fewer children than females, although the difference was not statistically significant.

On statistical grounds alone, it is unlikely that all cases of MM are the result of defective mitochondrial genes. The nuclear genome codes for the majority of the respiratory chain subunits, as well as controlling their transport into the mitochondrion and subsequent assembly into functional enzyme complexes. Transcription and translation of the mitochondrial genome are also dependent on nuclear products. ${ }^{70}$ Limited analysis of mitochondrial DNA in families with MM by means of restriction enzyme analysis has excluded major deletions of leucocyte mitochondrial DNA in patients, although this approach clearly does not exclude the presence of small deletions or pathologically significant mutations outside restriction sites. ${ }^{71}$ Evidence that MM may be caused by mutant nuclear genes is provided by Schapira et al ${ }^{72} 73$ who showed that some patients with complex I defects have a specific deficiency of the $24 \mathrm{kd}$ iron sulphur protein which is a nuclear product.

Isolated cases of MM, which comprise the majority of patients, could be the result of non-genetic phenocopies, autosomal recessive genes, fresh mutation of mitochondrial DNA, or new dominant mutations. There was no obvious increase in paternal age in this study to support the last possibility, although the data were not analysed statistically, mainly because of the paucity of data pertaining to normal paternal age over the relevant time. Paternal age in the UK during the first half of this century was slightly higher than that since $1960,{ }^{74}$ so it is unlikely that there was a paternal age effect in this series. This does not exclude the possibility of fresh dominant mutation in some cases of MM. It is possible that mutation of mt DNA in ova occurs more frequently with increasing age, but again there was no evidence of a maternal age or birth order effect in this study.

The mitochondrial myopathies are clearly genetically heterogeneous and it appears likely that these diseases may be caused by defective mitochondrial, autosomal dominant, or autosomal recessive genes. Until the nature of these has been determined, it seems reasonable to use empirical recurrence risk estimates for genetic counselling.

We wish to thank all the physicians who allowed us to study their patients, Dr Sarah Bundey for helpful comments at an early stage of this study, and Mrs Marjorie Gilbert for technical assistance. The biochemical investigations were performed by $\mathrm{Mr}$ Mark Cooper and Dr David Hayes. Financial support was provided by the Muscular Dystrophy Group of Great Britain, the Brain Research Trust, and the Chartered Society of Queen Square.

\section{References}

1 Olson W, Engel WK, Walsh GO, Einaugler R. Oculocraniosomatic neuromuscular disease with 'ragged red' fibres. Arch Neurol 1972;26:193-211.

2 DiMauro S, Bonilla E, Zeviani M, Nakagawa M, DeVivo DC. Mitochondrial myopathies. Ann Neurol 1985;17:521-38.

3 Petty RKH, Harding AE, Morgan-Hughes JA. The clinical features of mitochondrial myopathy. Brain 1986;109:915-38.

4 Morgan-Hughes JA, Hayes DJ, Cooper M, Clark JB. Mitochondrial myopathies: deficiencies localised to complex I and complex III of the mitochondrial respiratory chain. Biochem Soc Trans 1985;13:648-50.

5 Hudgson P, Bradley WG, Jenkison M. Familial mitochondrial myopathy. A myopathy with disordered oxidative metabolism in muscle fibres. Part 1. Clinical, electrophysiological and pathological findings. J Neurol Sci 1972;16:343-70.

6 Egger J, Wilson J. Mitochondrial inheritance in a mitochondrially mediated disease. $N$ Engl J Med 1983;309:142-6.

7 Morgan-Hughes JA, Darveniza P, Kahn SN, et al. A mitochondrial myopathy characterised by a deficiency in reducible cytochrome b. Brain 1977;100:617-40.

8 Morgan-Hughes JA, Darveniza P, Landon DN, Land JM, Clark JB. A mitochondrial myopathy with a deficiency of respiratory chain NADH Co-Q reductase activity. J Neurol Sci 1977;43: 27-46.

9 Haldane JBS, Smith CAB. A simple exact test for birth-order effect. Ann Eugen 1947;14:117-24. 
${ }^{10}$ Emery AEH. Methodology in medical genetics. 2nd ed. Edinburgh: Churchill Livingstone, 1986:140-53.

$"$ Bastiaensen LAK, Joosten EMG, de Rooij JAM, et al. Ophthalmoplegia-plus, a real nosological entity. Acta Neurol Scand 1978;58:9-34.

12 Kamieniecka Z. Myopathies with abnormal mitochondria. A clinical, histological and electrophysiological study. Acta Neurol Scand 1977;55:57-75.

13 Holliday PL, Climie ARW, Gilroy J, Mahmud MZ. Mitochondrial myopathy and encephalopathy. Three cases - a deficiency of NADH CoQ reductase. Neurology (Minneap) 1983;33: 1619-22.

14 Przybojewski JZ, Hoffman H, de Graaf AS, et al. A study of a family with inherited disease of cardiac and skeletal muscle. Part I. Clinical, electrocardiographic, electrophysiological and electron microscopic studies. S Afr Med J 1981;59:363-73.

15 d'Agostino AN, Ziter FA, Rallison ML, Bray PF. Familial myopathy with abnormal muscle mitochondria. Arch Neurol 1968;18:388-401.

${ }^{16}$ Leshner RT, Spector RH, Seybold M, et al. Progressive external ophthalmoplegia (PEO) with ragged-red fibres: an intrafamilial study. Neurology (Minneap) 1978;28:364-5.

${ }^{17}$ Schnitzler ER, Robertson WC. Familial Kearns-Sayre syndrome. Neurology (Minneap) 1979;29:1172-4.

${ }^{18}$ Hart ZW, Chang CH, Perrin EVD, Neerunjun JS, Ayyar R. Familial poliodystrophy, mitochondrial myopathy and lactate acidaemia. Arch Neurol 1984;34:180-5.

14 van Biervliet JPGM, Bruinvis L, Ketting D, et al. Hereditary mitochondrial myopathy with lactic acidemia, a de ToniFanconi-Debre syndrome, and a defective respiratory chain in voluntary striated muscles. Pediatr Res 1977;11:1088-93.

20) Sengers RCA, ter Haar BGA, Trijbels JMF, Willems JL, Daniels $O$, Stadhouders AM. Congenital cataract and mitochondrial myopathy of skeletal and heart muscle associated with lactic acidosis after exercise. J Pediatr 1975;86:873-80.

21 Okamura K, Santa T, Nagae K, Omae T. Congenital oculoskeletal myopathy with abnormal muscle and liver mitochondria. J Neurol Sci 1976;27:79-91.

${ }^{22}$ Shy GM, Gonatas NK, Perez M. Two childhood myopathies with abnormal mitochondria. Brain 1966;89:133-58.

23 Tamura K, Santa T, Kuroiwa Y. Familial oculocranioskeletal neuromuscular disease with abnormal mitochondria. Brain 1974;97:665-72.

24 Riggs JE, Schochet SS, Fakadej AV, et al. Mitochondrial encephalomyopathy with decreased succinate-cytochrome c reductase activity. Neurology (Minneap) 1984;34:48-53.

${ }^{25}$ Minchom PE, Dormer RL, Hughes IA, et al. Fatal infantile mitochondrial myopathy due to cytochrome c oxidase deficiency. J Neurol Sci 1983;60:453-63.

${ }^{26}$ Miyabayashi S, Narisawa K, Tada K, et al. Two siblings with cytochrome c oxidase deficiency. J Inher Metab Dis 1983;6: 121-2.

27 Buscaino GA, De Giacomo P, Mazzarella L. Two cases of so called mitochondrial myopathy. In: Canal N, Scarlati G, Walton J, eds. Muscle diseases. International Congress Series No 186. Amsterdam: Excerpta Medica, 1970:112-5.

${ }^{28}$ Mechler F, Fawcett PR, Mastaglia FL, Hudgson P. Mitochondrial myopathy: a study of clinically affected and asymptomatic members of a six generation family. J Neurol Sci 1981;50: 191-200.

${ }^{29}$ Egger J, Lake BD, Wilson J. Mitochondrial cytopathy: a multisystem disorder with ragged red fibres on muscle biopsy. Arch Dis Child 1981;56:741-52.

30) Smeraldi RS, Fabio G, Vanoli M, et al. Discordant HLA haplotype segregation in a family with progressive external ophthalmoplegia and ragged red fibres. J Neurol Neurosurg Psychiatry 1983;46:787-8.

31 Rosing HS, Hopkins LC, Wallace DC, et al. Maternally inherited mitochondrial myopathy and myoclonic epilepsy. Ann Neurol 1985;17:228-37.
${ }^{32}$ Yamamoto T, Beppu H, Tsubaki T. Mitochondrial encepha myopathy: fluctuating symptoms and CT. Neurology (Minneapt) 1984;34:1456-60.

33 Washington L, Ginsberg A, Sumi SM. Dominantly inheritêd muscular dystrophy with ragged-red fibers and abnornol mitochondria. Ann Neurol 1980;8:123.

${ }^{34}$ Barron SA, Heffner RR, Zwirecki R. A familial mitochondr myopathy with central defect in neural transmission. Arch Neurol 1979;36:553-6.

35 Iannocone ST, Griggs RC, Markesbery WR, Joynt RJ. Familiagl progressive external ophthalmoplegia and ragged red fibełs. Neurology (Minneap) 1974;24:1033-8.

${ }^{36}$ Tsairis P, Engel WK, Kark RAP. Familial myoclonic epilepsy syndrome associated with skeletal muscle mitochondrial abnen malities. Neurology (Minneap) 1973;23:408.

${ }^{37}$ Pepin B, Mikol J, Goldstein G, Aron JJ, Lebuisson D Familial mitochondrial myopathy with cataract. $J$ Neurol 1980;45:117-33.

${ }^{38}$ Calzetti S, Lemignani F, Marbini A, Savi M, Bragaglia MU Immunological abnormalities in a family with progressioe external ophthalmoplegia. J Neurol Sci 1983;61:13-20.

${ }^{39}$ Tassin S, Walter GF, Brucher JM, Rousseau JJ. Histochemi and ultrastrucutural analysis of the mitochondrial changes ima familial mitochondrial myopathy. Neuropathol Appl Neurobiol 1980;6:337-47.

40) Sasaki H, Kuzuhara S, Kanazawa I, Nakanishi T, Ogata $\$$ Myoclonus, cerebellar disorder, neuropathy, mitochonderal myopathy and ACTH deficiency. Neurology (Minneqf) 1983;33:1288-93.

41 Walter GF, Tassin S, Brucher JM. Familial mitochondride myopathies. Acta Neuropathol 1981;suppl VII:283-6. $\infty$

42 Lapresle J, Fardeau M, Godet-Guillain J. Myopathie distâ.e et congenitale, avec hypertrophie des mollets. J Neur\& $\mathbb{S e}_{i}$ 1972;17:87-102.

43 Jankowicz E, Berger H, Kurasz S, Winogrodzka W, Eljązz Familial progressive external ophthalmoplegia with abnorra muscle mitochondria. Eur Neurol 1977;15:318-24.

44 Leveille AS, Newell FW. Autosomal dominant Kearns-Sa禺e syndrome. Ophthalmology 1980;87:99-108.

45 Kinoshita M, Wakata N. Lipid storage myopathy in fami $\overrightarrow{\vec{n}}$ hyperlipoproteinaemia. Arch Neurol 1984;41:551-4.

46 Vilming ST, Dietrichson P, Isachsen MM, Lovvik L, Heiberg A. Late-onset hereditary myopathy with abnormal mitochond and progressive dementia. Acta Neurol Scand 1986;73:502-6.

47 Spiro AJ, Moore CL, Prineas JW, Strasberg PM, Rapin I.A cytochrome-related inherited disorder of the nervous system and muscle. Arch Neurol 1970;23:103-12.

48 Boustany RN, Aprille JR, Halperin J, Levy H, Delong G Mitochondrial cytochrome deficiency presenting as a myopathy with hypotonia, external ophthalmoplegia and lactic acidosis? an infant and as fatal hepatopathy in a second cousin. AFn Neurol 1983;14:462-70.

49 Johnson MA, Turnbull DM, Dick JJ, et al. A partial deficiency of cytochrome c-oxidase in chronic progressive external ophth moplegia. J Neurol Sci 1983;60:31-53.

5) Shapira Y, Cederbaum SD, Cancilla PA, Nielsen D, Lippe B $\overline{\bar{M}}$. Familial poliodystrophy, mitochondrial myopathy and lasic acidaemia. Neurology (Minneap) 1975;25:614-21.

51 Fitzsimons RB, Clifton-Bligh P, Wolfenden WH. Mitochond myopathy and lactic acidaemia with myoclonic epilepsy, atadea and hypothalamic infertility: a variant of Ramsay-Hunt sydrome? J Neurol Neurosurg Psychiatry 1981;44:79-82.

52 Monnens L, Gabreels F, Willems J. A metabolic myopa associated with chronic lactic acidemia, growth failure and ne deafness. J Pediatr 1975;80:983.

53 Rawles JM, Weller RO. Familial association of metabotic myopathy, lactic acidosis and sideroblastic anaemia. $A m J M d$ 1974;56:891-7.

54 Fukuhara N, Tokiguchi S, Shirakawa S, Tsubaki T. Myocloßi epilepsy associated with ragged red fibres (mitochond黑al 
abnormalities): discase entity or syndrome. J Neurol Sci 1980;47:117-33.

55 Kamieniecka Z, Sjo O. Ptosis, ophthalmoplegia and mitochondrial abnormality. In: Scarlato G, Cerri C, eds. Mitochondrial pathology and muscle disease. Padova: Piccin, 1980:73-85.

56 Giles RE, Blanc H, Cann HM, Wallace DC. Maternal inheritance of human mitochondrial DNA. Proc Natl Acad Sci USA 1980;77:6715-9.

57 Lansman RA. Avise JC. Huettel MD. Critical experimental test of the possibility of "paternal leakage" of mitochondrial DNA. Proc Natl Acad Sci USA 1983;80:1969-71.

58 Anderson S, Bankier AT, Barrell BG, et al. Sequence and organisation of the human mitochondrial genome. Nature 1981;290:457-65.

${ }^{59}$ Chomyn A, Mariottini P, Cleeter MWJ, et al. Six unidentified reading frames of human mitochondrial DNA encode components of the respiratory chain NADH dehydrogenase. Nature 1985;314:592-7.

6) Chomyn A, Mariottini P, Cleeter MWJ, et al. Functional assignment of the unidentified reading frames of human mitochondrial DNA. In: Quagliariello E, et al, eds. Achievements and perspectives of mitochondrial research. Vol II. Biogenesis. Amsterdam: Elsevier Science Publishers, 1985: 259-75.

61 Solignac M, Monnerot M, Mounolou JC. Mitochondrial DNA in Drosophila mauritiana. Proc Natl Acad Sci USA 1983;80: 6942-6.

62 Hauswirth WW, Laipis PJ. Mitochondrial DNA polymorphism in a maternal lineage of Holstein cows. Proc Natl Acad Sci USA 1982;79:4686-90.

${ }^{63}$ Hauswirth WW, van de Walle MJ, Laipis PJ, Olivo PD. Heterogeneous mitochondrial DNA D-loop sequences in bovine tissuc. Cell 1984;37:1001-7.

${ }^{64}$ Brown WM, George M, Wilson AC. Rapid evolution of animal mitochondrial DNA. Proc Natl Acad Sci USA 1979;76:1967-71.
65 Blanc H, Chen K, d'Amour MA, Wallace DC. Amino acid change associated with the major polymorphic Hinc II site of oriental and Caucasian mitochondrial DNAs. Am J Hum Genet 1983;35:167-76.

th Brown WM. Polymorphism in mitochondrial DNA of humans as revealed by restriction endonuclease analysis. Proc Natl Acad Sci USA 1980;77:3605-9.

67 Cann RL, Stoneking M, Wilson AC. Mitochondrial DNA and human evolution. Nature 1987;325:31-6.

${ }^{6 x}$ Horai S, Gojobori T, Matsunaga E. Mitochondrial DNA polymorphism in Japanese. I. Analysis with restriction enzymes of six base pair recognition. Hum Genet 1984;68:324-32.

69 Horai S, Matsunaga E. Mitochondrial DNA polymorphism in Japanese. II. Analysis with restriction enzymes of four or five base pair recognition. Hum Genet 1986;72:105-17.

70 Attardi G. Organization and expression of the mammalian mitochondrial genome: a lesson in economy. Trends Biochem Sci 1981;6:86-9, 100-3.

71 Harding AE, Holt IJ, Morgan-Hughes JA. Restriction enzyme analysis of mitochondrial DNA in patients with mitochondrial myopathy. J Med Genet 1987;24:243A.

72 Schapira AHV, Cooper JM, Morgan-Hughes JA, Clark JB. Evidence for molecular heterogeneity in human complex I deficiency. Muscle Nerve 1986;9(suppl 5):183.

73 Schapira AHV, Cooper JM, Morgan-Hughes JA, et al. The molecular basis of mitochondrial myopathies: polypeptide analysis in complex I deficiency. Lancet (in press).

74 Bundey S, Harrison MJG, Marsden CD. A genetic study of torsion dystonia. J Med Genet 1975;12:12-9.

Correspondence and requests for reprints to Dr A E Harding, Institute of Neurology, Queen Square, London WC1N 3BG.

\section{Note added in proof}

Since this paper was submitted Holt et al (Nature 1988;331:717-9) reported that in nine of 27 patients with MM a proportion of muscle, but not leucocyte, mt DNA molecules was partly deleted. 